\title{
不均質な行動原理を有する移動ロボット群の協調作業†
}

\author{
倉 林 大 輔*.太田順** \\ 新井民夫**. 野 口克 行** \\ Efficiency of a Group Consisted of Robots with Heterogeneous Motion Algorithms ${ }^{\dagger}$ \\ Daisuke Kurabayashi*, Jun Ota**, \\ Tamio ARAi* and Katsuyuki NoguCHI**

\begin{abstract}
In this paper, we propose a heterogeneous robot group for cooperative task execution. The "heterogeneous" robot group is composed of autonomous robots which have different motion algorithms. In this paper, we investigate characteristics of the heterogeneous robot groups by simulations of multi-agent taveling salesman problem, which we can hardly solve by centralized algorithm. Then we propose an algorithm to arrange balance of mixture of robots driven by different algorithms. We verify the efficiency of the autonomous heterogeneous robot group by simulations.
\end{abstract}

Key Words: heterogeneous robot group, autonomous mobile robot

\section{1. 序論}

工場内での生産活動に対するロボットの適用が進んだ今 日，より高度な行動の実現が期待されている。とりわけ，複 数のエージェントが相互作用を及ほし合って新たな機能を 生み出す, 創発機能の研究に注目があつまっている。ここで エージェントとは，自律ロボットや人間など，自分で自分の 行動を決定できる主体を指す，現在，創発機能の基本原理の

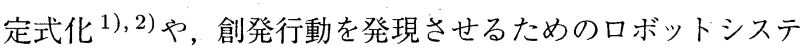
厶 ${ }^{3) \sim 6)}$ の研究が精力的に行われている.これらの中には, 生

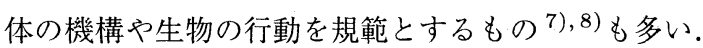

創発現象の応用形態には，生じる現象自体が事前の想定を 超えて創発的であることと，ある目的を達成する手段が，設 計者の想定を超えて適応的であることの 2 面がある ${ }^{9)}$. 生物 の行動を規範とする研究には，進化における創発的変化のよ うに，特定の目的を想定せずに，システムを創発的な変化に まかせようという意見もある。しかし，我々の社会における ロボットは，生物が自分の遺伝子の発展を目的としているの と異なり，何らかの夕スク達成を目的として存在している。 そのため, その行動は夕スク達成に対して，明示的に合目的

†日本機械学会ロボティクス・メカトロニクス講演会' 98 で発 表 $(1998 \cdot 6)$

* 理化学研究所 工学基盤研究部 和光市広沢 2-1

** 東京大学 工学部 東京都文京区本郷 7-3-1

* RIKEN: The Institute of Physical and Chemical Research, Wako

** University of Tokyo, Hongo, Bunkyo-ku, Tokyo (Received January 27, 1999)

(Revised June 24, 1999)
であることが望まれている，ただし，マルチエージェント系 では，群全体の動作を合目的とするために，個々のロボット の動作アルゴリズム設計論を単純に導き出すことができない. それゆえに，これまでにも多くの文献で群ロボットに対する 効率的な動作アルゴリズムを追求する研究が行われてきた. これらにおけるロボットの行動原理は大きく計画型行動と反 射型行動の 2 種に分類される。

計画型行動（例えば $\left.{ }^{10), 11)}\right)$ は，作業実行についての完全 性や最適性が取り扱えるという長所を有するが, 動的な環境 における適応性に欠け, 計算量が多いという短所を有する。 反射型行動（例えば ${ }^{12)}$, 13) ) は，この逆の特徴を有する. 従 来の研究では, ロボット群内において, 上記のどちらか一方 の行動原理のみを有するものがほとんどであった。

これに対し山田は, 動的環境において熟考して（計画し て）行動すべきか, 即応行動を行うかを, ベイジアンネット ワークに基づく成功確率計算によって選択し，行動を決定す るエージェント14)を提案している。このような, 行動を決 定する原理の多様化は, 多様なロボット, あるいは人間との 協調へと発展する上でも極めて重要である。そのため，群と いうエージェントの集団の中で，異なる行動原理が混在する 「不均質な」群の行動を解明することが重要であると考えら れる. 本研究では, 反射型行動と計画型行動という典型的な 行動原理を混在させたロボット群を提案する。この不均質な 行動原理を有するロボット群の性質について，その挙動を明 らかにし，その行動原理分化を自動的に獲得する，ロバスト なロボット群の構築を実現する.

本論文の構成は以下の通りである。はじめに, 本論文の背 
景と目的を述べた。次に，不均質な行動原理を有する移動口 ボット群のモデル化を行う. 群内での行動原理構成比と作業 効率の関係をシミュレーションにより考察した後, 漸進的な 学習による行動原理構成比の自律的な獲得手法を実現する. 最後に結論を述べる。

\section{2. 不均質な行動原理を有する群のモデル化}

\section{1 問題設定}

はじめに，自律移動ロボット群により解決しようとする問 題を設定する．移動ロボットの適用が期待される作業には， ごみ収集，配送，点検など，2次元平面内に作業対象が散在 するものが数多く存在する．本論文では，このような作業を 行商人問題 (Traveling Salesman Problem, TSP) にモデル 化し，取り上げる．TSPにおける「都市」を作業地点とし， ロボットが全ての作業地点に 1 度以上到達したとき，作業の 完了とする.

作業を実行するにあたり，ロボットを以下のように設定 する。

・ロボットは半径 $r$ の円形, 全方向に移動可能.

・ロボットは相互に通信を行なわない.

・自己位置は正しく認識できる.

・必要であれば，作業地点の地図を生成することができる。 自律ロボットは，現実には知覚可能な領域が，自己位置から 一定の範囲に限定されるが，本論文では問題の単純化のため に，個々のロボットは領域内に残さ机ている作業地点を地図 として随時知ることができるものとした.

TSPでは，作業地点数増大に対して，巡回順序を決定する 計算量が爆発的に増大する。さらに，複数のロボットに対し て，最適な分配順序を決定する問題は，計算量の面から極め て困難な問題として知られている。このため，本論文では， 個々のロボットが自律的与えられた作業地点全てをできるだ け短い時間で，ロボット群により巡回することが本作業の目 的である。

2.2 不均質な行動原理を有するロボット群のモデル化 本論文では，"不均質な行動原理を有する群”を次のよう に定義する。

不均質な行動原理を有する群とは，同一の目的を達成する ための行動決定アルゴリズムが複数ある問題に対して，群を 構成する自律ロボットが異なるアルゴリズムを取ることを許 す群である.

ロボットの行動決定アルゴリズムは多数存在するが, おの おの最適な性能を発揮する状況が異なる。また，個々の口 ボットのアルゴリズムが合目的であっても，群全体の動作を 合目的にするものとは限らない。マルチエージェントシステ ムでは, 個々のロボットを取り巻く状況は, 他のエージェン トや環境によって変化するため，ロボット側で状況判断と行 動アルゴリズム決定を行うことが必要となる．自律ロボット によって構成される群において，行動原理が不均質となるの は必然であるといえる。

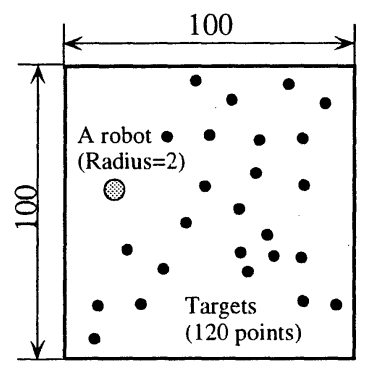

Fig. 1 Environment for a robot group

各ロボットがアルゴリズムを選択するにあたって，その選 択肢には多様なアルゴリズムが存在する。本論文では, 問題 を単純化するために，TSPにモデル化された作業の実行アル ゴリズムとして, 計画型行動と反射型行動という 2 種に限定 し，次のように設定する。

計画型行動 ロボットは, 作業地点の地図より，それらを隼 最短で巡回する順序を決定し, 移動する. 作業地点の変化, すなわち他のロボットにより作業が既に行わ机たという情 報が得られた場合, 再度計画を行う。

反射型行動 ロボットは作業地点の地図より, 現在の自己位 置からもっとも近い，未作業の作業地点に向って移動する. 計画型行動，反射型行動いず狄においても，個々のロボッ トは個々の動作のみを計画し，群全体を扱うことはしない， この計画型行動と反射型行動は，行動原理として極端な例と いえるが，本論文ではこの中間段階については扱わない。 な お，各ロボットに拈ける計画アルゴリズム（TSP 解法）に ついて，準最適解の算出手法として，パフォーマンスが高い とされる発見的手法の 1 つ, CCAO(Convex-hull, Cheapest insertion, Angle selection, Or-opt) 法 ${ }^{15)}$ を適用するものと した。この手法では，作業地点数が 100 程度の場合，十分な 速度が得られるため，計画に要する時間については，計画型 行動と反射型行動の差異を考慮しないものとした。

\section{3. 不均質な行動原理を有するロボット群の挙動}

不均質な行動原理を有するロボット群において，群を構成 するロボットの台数と, 行動原理の混在比との関係について, シミュレーションにより考察する。

シミュレーション環境を，Fig. 1 に示す。ロボットは単位 長さ $100 \times 100$ の正方形形状領域中を移動する。領域内には, 120 箇所の作業地点が点在する。作業地点およびロボットの 初期位置はランダムに決定される。ロボットの半径を単位長 さ 2 とし，1 ステップ時間あたり単位長さ 1 の速度で, 全方 向に移動可能であるものとした。

シミュレーションにおけるロボットの相互衝突回避は，デッ ドロック発生によるシミュレーション中断をさけるために， シミュレータ内部でロボットにID 番号を割りあて, ID 番号 の小さいロボットを優先的に動作させ，他のロボットはその ロボットと重ならない位置まで避ける，あるいは重ならない 位置に留まるというアルゴリズムを設定した。 

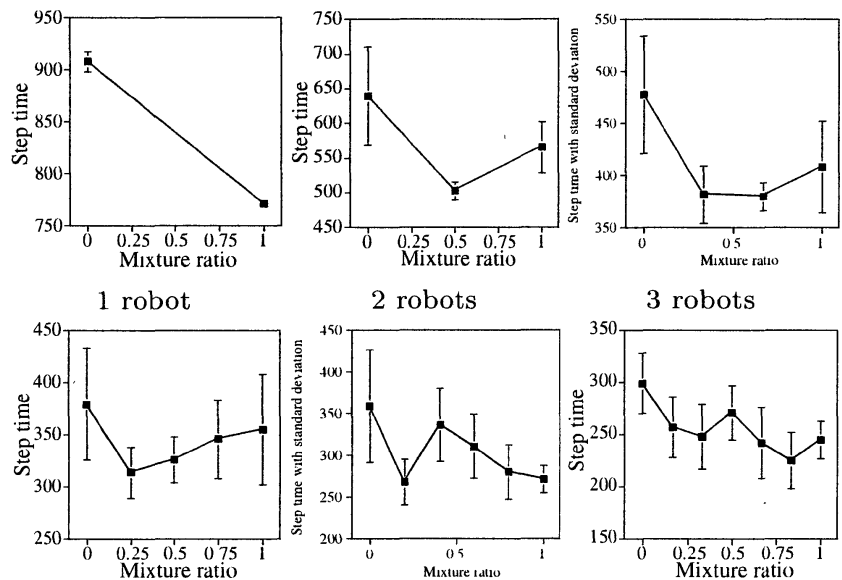

2 robots

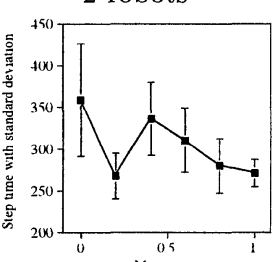

3 robots

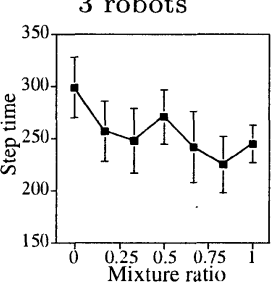

4 robot

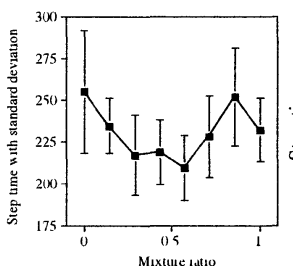

5 robots

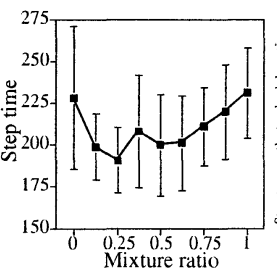

6 robots

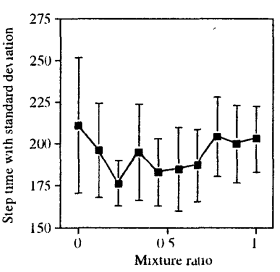

7 robot

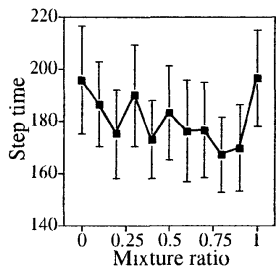

8 robots

9 robots

10 robots

Fig. 2 Average and standard deviation of working time

シミュレーションでは，1台から 10 台までロボット台数を 変化させた．各ロボット台数において，1台も計画型がいな い場合, 1 台のみ計画型の場合, $\cdots$, 全て計画型の場合, と いうようにしらみつぶしに混在比を設定した。このシミュ レーションにおいては，群内での計画型行動，反射型行動を 行うロボットの比率 (台数) を固定し，あらかじめ計画型行 動を行うロボット，反射型行動を行うロボットを決定してお く，その比率および個々のロボットがとる行動原理は, 作業 終了まで変化しないものとした。ロボットの初期位置および 作業地点の配置は乱数によって 10 組生成し，各条件に対し て同様の 10 組を適用することで，ロボット台数・混在比に 対する作業完了時間の評価を行った，台数毎の作業完了時間 の平均と標準偏差を Fig. 2 に示す。また，ロボット 3 台の場 合の軌跡の例を Fig. 3 に示す.

ロボットが 1 台しかいない場合, そのロボットの計画結果 を邪魔する要素がないため, 計画型行動で作業をするのが効 率的である。しかし, 台数の増大に伴い, 他のロボットの存 在によって, 計画の有効性が薄れてくる. 計画型行動では最 終的な移動量を最小化するために，ロボットの現在位置から 最短距離にない作業地点に向かうことが多い.すなわち, 短

期的な視点で見た場合，損な動作を行うことになる．計画 結果の遂行途中で，他のロボットの行動によって計画を行っ た時点と異なる状況が生成されていると, 計画結果の一部 しか実行できず，損な動作の影響によって作業に要する時間 (ステップ数) が増大する。また，複数のロボットが近接し た場合，計画結果が一致してしまうことがあり，同一の作業 地点に複数のロボットが群がる傾向がある. Fig. 3(a)では, 270[step] ころから，2 台のロボットがさかんに計画経路を変 更し，ロボットの軌跡が細かく変化していること, 330[step] 附近で 3 台のロボットが同一の目標を追い掛けていることが 示されている.

一方反射型動作は，定義によりロボットの現在地より最短 距離にある作業目標点に向かうため，短期的に見た場合，効 率の高い行動を行うこととなる。しかし，作業全体を通して 見た場合, 作業の後半になると, 作業地点の取りこほしが目 立ち，作業領域の隅に散在する目標点を巡回することになり， 作業効率が低下してしまう. Fig. 3(c) の例では, 270[step] の時点で (a)(b) に比べ, 作業領域の広い範囲に作業目標点 が残されていること，330[step] で1つ残された作業目標点 に，3台のロボットが一斉に向かっていることが示されてい る. Fig. 3(b) は, 計画型行動を行うロボットが 2 台, 反射型 行動を行うロボットが 1 台の場合の軌跡である。不均質なロ ボット群では, 特性の異なるロボットが混在し, 大局的な最 適性と, 短期的な最適性の追求がエージェント間で分担され ているために，作業効率が向上していると考えられる (Fig. $3(\mathrm{~b}))$.

Fig. 4 では, 計画型行動を行うロボットのみから構成され る群の作業達成時間を 1.0 として正規化した場合の, 群内の ロボット台数に対する不均質な群の最良結果を表したもので ある。このシミュレーションでは, 計画型行動を行うロボッ 卜のみから成る均質な群に比べ, 最も良い 8 台, 10 台の場 合で約 $13 \%$ の作業時間短縮が実現されている。

しかし，Fig. 5 に示すように，最良結果を与える混在比に ついては, ロボット台数に対して単純な関数として容易に定 式化可能なものではない。そのため,この結果から、ロボッ 卜群に対する行動原理構成比の設計論を展開することは困 難である。また, 行動原理構成比率がシミュレーションを通 じて固定さ机たままであるため，作業の進展に伴う作業環境 の変化に適応できていないことが考えられる，次章では，作 業環境の変化に対して, 作業実行中に動的に行動原理構成比 を変化させるアルゴリズムを提案し, 自律的な適応を行う口 ボット群を実現する。

\section{4. 行動原理構成比の自律的な獲得}

\section{1 構成比獲得アルゴリズム}

前章において, 不均質な行動原理を有する群の優位性とそ の条件を考察した。その結果, 群を構成するロボットの数, 作業の進行状沉などによって適切な混在比は変化することが 明らかになった，そのため, 不均質な行動原理を有する群内 


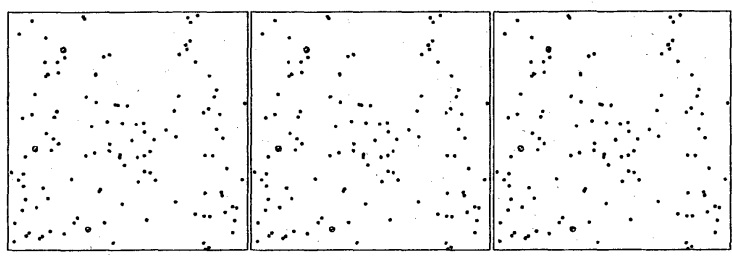

Initial state

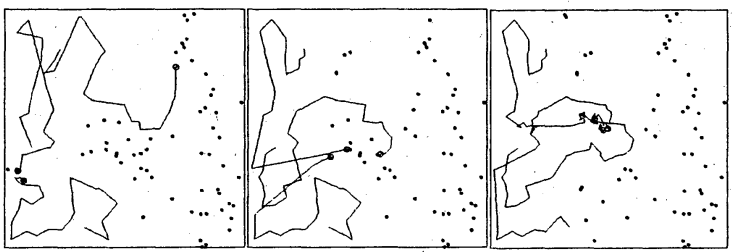

150 [step]

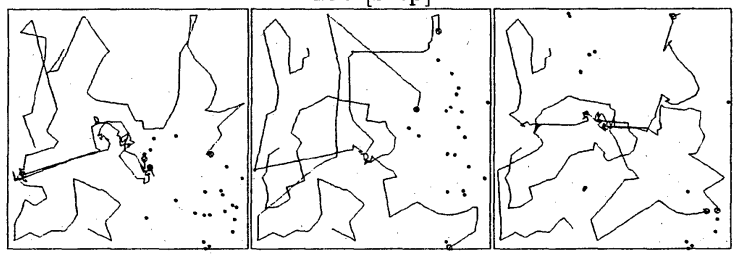

270 [step]

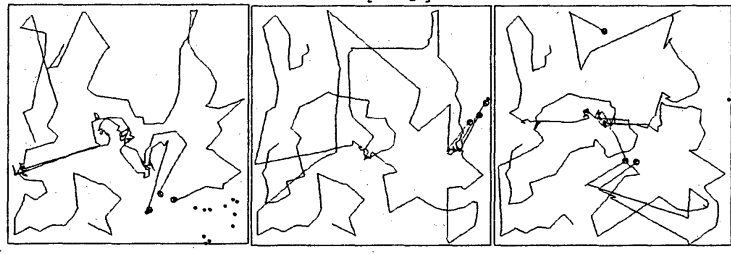

330 [step]

(a) Planning only (b) Heterogeneous (c) Reactive only

Fig. 3 Comparison of trajectories

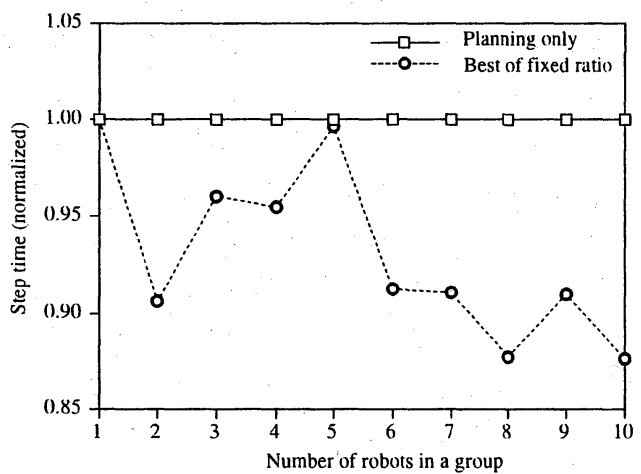

Fig. 4 Best results of working time

において, 行動原理の構成比をあらかじめ設計するのは困難 である. そこで, 個々の自律ロボットが状態を推定して, 自 己の行動原理を動的に選択することで, 群全体として高い適 応性を発揮することを可能とするアルゴリズムを実現する。

仮定により，個々のロボットは，他のロボットと情報のゃ りとりは行わない. そのかわり, ロボットが向かっていた作 業地点を, 他のロボットに横取りされたか否かという情報を 利用し, 環境を介して作業の遂行状態や, 現在選択している 行動原理の有効性を推測する. その結果に基づき, 行動原理 を変化させる. 本報では, 状態推定を含む行動原理選択アル

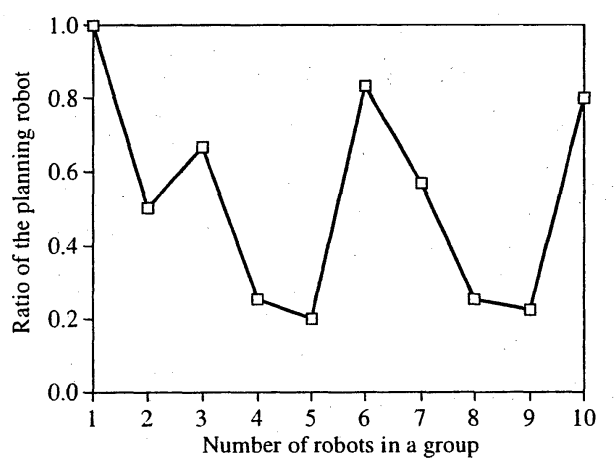

Fig. 5 Mixture ratios at the best results

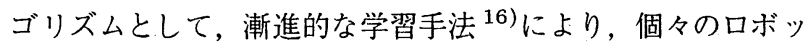
トの行動原理選択を行う.

個々のロボットは, 各ステップ時間ごとに, 作業地点の地 図を更新し，作業地点に他のロボットが先に到着したか否か を観測する．自分がある作業地点に到着するか，他のロボッ トがある作業地点に到着した時点で, 学習パラメ夕の更新と, 行動原理の選択を行う.

\section{2 学習手法の定式化}

[学習式]

計画型行動を行うロボットは, 計画により, 訪問する作業 地点の順列を生成し, その筆頭の作業地点から順に移動目標 としていく，反射型の場合は，自身から最も近い未作業の作 業地点を移動目標とする。

各ロボットは，自分がそれまで移動目標としていた作業地 点に, 他のロボットに先駆けて到着することができた場合, その時点で用いていた行動原理に対して「成功」と判断し, 新たな移動目標を設定する。移動目標に他のロボットが先に 到着した場合,「失敗」とし, 新たな移動目標を設定する. 現 在の移動目標ではないが, 計画型における計画結果の順列内 の作業地点へ他のロボットが先に到着した場合, 現在実行中 の計画結果が全く無駄になったわけではないが, 再度計画を 行う必要性が生じることから,「再計画」という評価を与える.

判定が行わ机た時点で, 計画型行動および反射型行動に対 して 0 以上 1 以下に正規化さ机た報酬を決定する．この報酬 に基づき, 式 (1)(2)によって, 計画型, 反射型それぞれの行 動を選択した際の報酬の期待値を更新する.

$$
\begin{aligned}
& E_{i p}(t)=K_{f} \cdot E_{i p}(t-1)+\left(1-K_{f}\right) \cdot P_{i p}(t-1)(1) \\
& E_{i r}(t)=K_{f} \cdot E_{i r}(t-1)+\left(1-K_{f}\right) \cdot P_{i r}(t-1)(2)
\end{aligned}
$$

ここで, $E_{i p}(t), E_{i r}(t)$ は，そ机ぞれステップ $t$ でのロボット $i$ の計画型行動, 反射型行動の報酬期待値, $P_{i p}(t), P_{i r}(t)$ は ステップ $t$ での行動に対する報酬を表す。 $K_{f}$ は, 報酬期待值 の更新割合を決定する係数である.

この期待值により, 式 (3) によって定める確率 $R_{i p}(t), R_{i r}(t)$ に応じて, 計画型行動あるいは反射型行動をとるべきとの判 断を行う. 
Table 1 Rewards

$$
\begin{aligned}
& R_{p t m p}=\max \left\{R_{i p}(t-1)+K_{d} \cdot \frac{E_{i p}(t)-E_{i r}(t)}{2}, R_{m i n}\right\} \\
& R_{r t m p}=\max \left\{R_{i r}(t-1)+K_{d} \cdot \frac{E_{i r}(t)-E_{i p}(t)}{2}, R_{m i n}\right\} \\
& R_{i p}(t)=\frac{\left(R_{p t m p}-R_{m i n}\right)\left(1-2 R_{m i n}\right)}{\left(R_{\text {ptmp }}-R_{m i n}\right)+\left(R_{r t m p}-R_{\text {min }}\right)}+R_{m i n} \\
& R_{i r}(t)=\frac{\left(R_{r t m p}-R_{m i n}\right)\left(1-2 R_{m i n}\right)}{\left(R_{\text {ptmp }}-R_{m i n}\right)+\left(R_{r t m p}-R_{m i n}\right)}+R_{m i n}
\end{aligned}
$$

ここで， $R_{\text {min }}$ は，ある行動原理に対する最小選択確率を 表す。すなわち，どちらかの報酬の期待值がたとえ 0 になっ ても， $R_{\text {min }}$ の確率でその行動原理を選択する可能性を残す ものである． $K_{d}$ は, 確率值を更新する度合を決定するパラメ 夕である。これらは，事前に与えられるものとする。

[報酬の決定]

各ロボットは,「成功」,「失敗」,「再計画」の判定に応じて, 自分が取りうる行動原理 2 種について評価となる報酬を決定 する.

計画型行動は，立てた計画が長期に渡って有効であるとの 予測の下，短期的に不利な行動をとる。このため，作業地点 への到達に成功した場合には作業全体の遂行に対して貢献の 大きな手法であるといえるが, 失敗した場合には, ロボット は無駄な動きを長時間にわたって行ったこととなり，作業遂 行に大きな損失を与える，そのため，計画型行動をとってい る場合, 成功には高い報酬を，失敗した場合には低い報酬を 与えるのが妥当といえる.「再計画」の場合, それまでの移動 量が必ずしも無駄になったとはいえないため, 計画型行動と 反射型行動の報酬の期待値を均一化する方向の報酬を与える ものとした。

反射型行動は，短期的に有利をな行動を繰り返す。そのた め, 成功あるいは失敗による差異は計画型動作ほど大きくな いと考えられる，ただし，反射型行動を取りつづけることは， 作業全体で見た場合不利な行動である。そこで，正規化する 数值範囲の中間値を報酬として与えるものとした.

以上の考察に基づき，行動をとった際の報酬は，Table 1 に示すテーブルから与えられるものとした。計画行動と反 射行動の報酬の間には, $P_{i p}+P_{i r}=1$ という拘束条件を与 え，常に双方の報酬期待值を更新するものとした. Table 1 に示さ机ている值は, 左側が計画型行動, 右側が反射型行 動に対して与えられる報酬値である。なお，初期状態では， $E_{i p}(0)=E_{i r}(0)=1$ とした. また, 初期状態では, 計画行 動を選択しているものとした。

\section{3 可変構成比のシミュレーション}

群内での行動原理構成比を自律的に更新する提案手法を用 い, 前章と同様の Fig. 1の作業領域におけるシミュレーショ

\begin{tabular}{|c|c|c|}
\hline & \multicolumn{2}{|c|}{ Current algorithm } \\
\hline Action result & Planning & Reactive \\
\hline Success & $\left(\begin{array}{lll}1.0 & 0.0\end{array}\right)$ & $(0.50 .5)$ \\
\hline Replanning & $\left(\begin{array}{lll}0.5 & 0.5\end{array}\right)$ & - \\
\hline Failure & $\left(\begin{array}{lll}0.0 & 1.0\end{array}\right)$ & $\left(\begin{array}{lll}0.5 & 0.5\end{array}\right)$ \\
\hline
\end{tabular}
ンを行った。シミュレーションにおいて，各行動原理選択の 最低確率 $R_{m i n}$ は 0.01 , パラメ夕 $K_{d}=0.5, K_{f}=0.5$ とし た. 作業に要したステップ数を Fig. 6 に示す.グラフ中の数

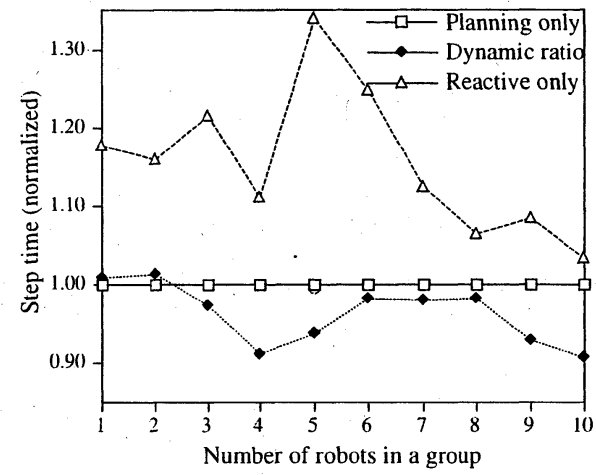

Fig. 6 Comparison of working time (normalized)

值は，群内の全てのロボットが計画型行動をとった場合の所 要時間を 1.0 として正規化したものである。提案手法により 実現される不均質な群との比較として, 全てのロボットが計 画型行動を行う場合と，全てのロボットが反射型行動を行う 群を用いた。また，群を構成するロボット台数と，行動原理 構成比の作業時間を通じた平均を Fig. 7 に，群規模による， 計画行動，反射行動により得られた報酬の作業時間を通じた 平均を Fig. 8 に示す.

群を構成するロボットの台数が少ない状況では, 計画型行 動が有利である．Fig. 8においても，ロボットが 7 台以下で は計画型行動の報酬が高く，そ狄以上の台数では反射型行動 の報酬が高くなっている，台数が少ない状態では，固定的に 計画行動を行う方が，反射行動を含む提案手法より効率がわ ずかに良い.しかし，ロボット台数が増加するにつれ，提案 手法が良好な結果を示し, 計画型行動のみで構成される均質 な群に比べ，最も良い 4 台，10 台の場合で約 $10 \%$ の効率向 上が得られた。 また，Fig. 7より，ロボット台数の増大によ り，計画型行動を中心とする群から，反射型行動を含む群へ 構成比が変化していることが示された。 なお，台数が 1 台で も，ロボットが $100 \%$ 計画型行動を行わないのは，最小確率 $R_{\text {min }}$ で反射型行動を選択することがあるためである。これ らシミュレーション結果より，自律的に行動原理構成比を獲 得する提案手法により，群の規模および作業の進行途中にお いて群内の行動原理構成比を動的に変更し, 均質な行動原理 による群を上回る効率を発揮できたといえる.

ここで, 作業の遂行状態と, 群内の行動原理の変化につい て考察する.Fig.9は，作業遂行までに要した時間（ステッ プ数）を開始時から終了時までの間で $1 / 4$ ずつの区間に区切 り，群内での，計画型行動を行うロボットの構成比の区間毎 平均を示したものである：Fig.10は，ロボット同士が密集 


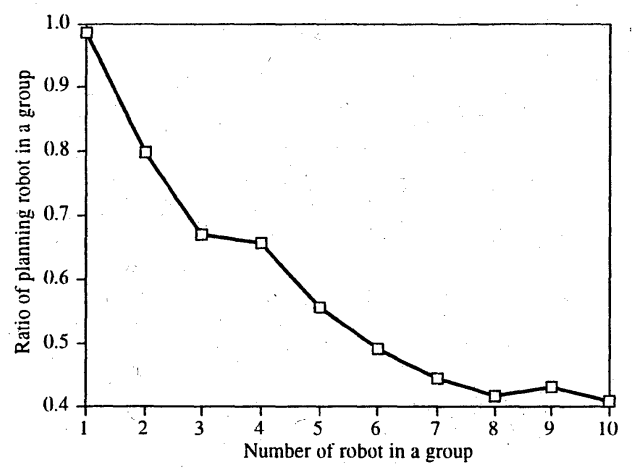

Fig. 7 Averaged ratio of planning robot

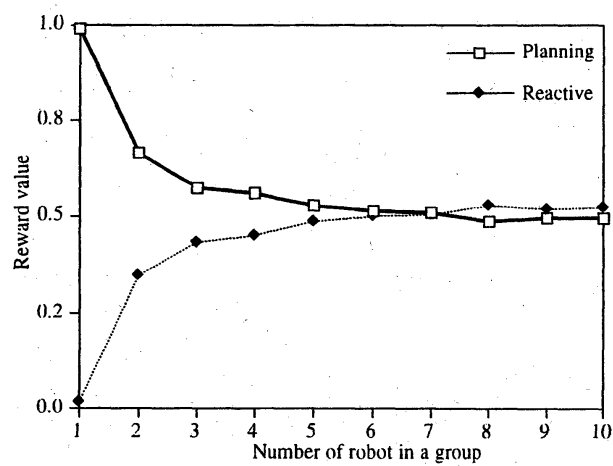

Fig. 8 Averaged reward of robot groups

しているか否かを式 (4)により評価した結果を示す. 式 (4) は，ロボット間の距離の逆数の和をとったもので, 群のロボッ トが拡散しているほど小さく，集中しているほど大きな值と なる.

$$
\text { Index_of_density }=\sum_{i \neq j}^{n} \frac{1}{\left\|p o s_{i}-p_{0} s_{j}\right\|}
$$

ここで, $n$ は群内のロボット総数, $p o s_{i}$, はロボット $i$ の位置 を表す。

Fig. 9より, 群内のロボットは，単数の場合を除いて，全 体としては時間経過と共に計画型行動の割合が減少する方向 に変化している．しかし， ロボット台数が 4 台以上の場合で は, 中盤 $($ Period $=2 / 4,3 / 4)$ にピークを持った山型の遷移を していることが示されている.すなわち，一度反射型行動の 割合が増大した後, 計画型行動が盛り返し, 再び反射型行動 が増大している．この現象を考察するにあたって Fig. 10を 参照すると，作業開始時から終了に向けて，ロボット同士は 一貫して集約されていくことが示されている．これらの結果 から，提案手法により動作するロボットは，以下のような行 動原理混在比の変化を生じていると考察される.

・作業地点が多数残されている作業序盤 $($ Period $=1 / 4)$ に おいては，手当たり次第に周囲の作業地点に向かう反射型 行動を行っても, 特に不都合が生じない.むしろ, 計画型 行動を行って失敗した場合のリスクが大きく，反射型行動 の比率が增大する.

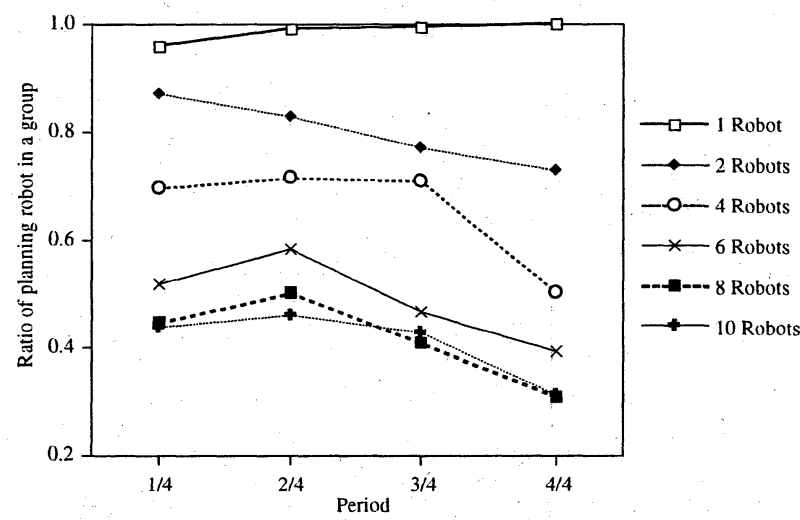

Fig. 9 Transition of ratio of planning robot in a group

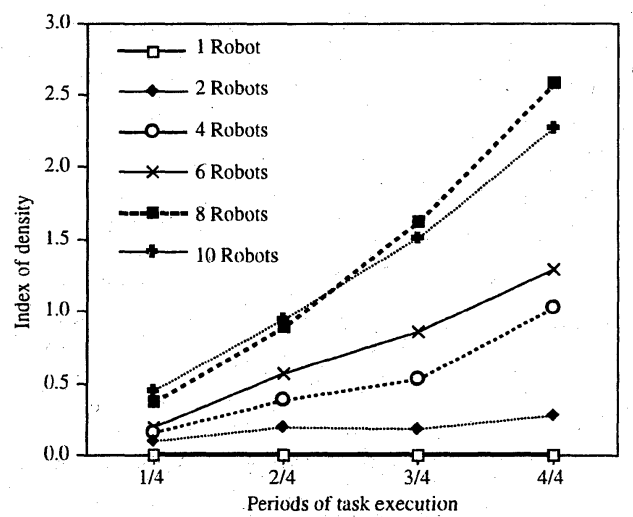

Fig. 10 Transition of index of density

・作業中盤 (Period=2/4-3/4) では，計画型行動をさまた げるほど他のロボットとの競合はまだ多くない。一方で序 盤の反射型行動で簡単に到達できる未作業の作業地点が減 少した結果, 反射型行動に比へ，移動経路長を最適化する 傾向を持つ計画型行動が有利となってくる.

・ロボットが残さ扎た作業地点に集中する作業後半 $(\operatorname{Period}=3 / 4-4 / 4)$ では, 作業地点に対する競合が顕在 化するため, 短期的に不利な動作を行う計画型行動をやめ, 反射型行動に切り替えるロボットが増大してくる.

このように，作業の進行状況に適応して行動原理構成比を変 化させ，作業効率を向上させているといえる．また，行動原 理構成比の絶対的な值も, 群を構成するロボットの台数, す なわち群規模の大小によって自律的に獲得さ机ていることが 示された。

これらの結果により, 提案手法は作業の進行状況および群 規模に応じて自律的に群内での行動原理構成比を適応させる ことを可能とし，高効率な作業遂行を可能としたことが示さ れた。

\section{4 計画型行動の計算時間導入に関する考察}

本論文では，単体のロボットにおける計画の計算時間に関 しては, 計画型行動と反射型行動との差異はないものとして きた。しかし現実には，計画に要する計算時間が，反射型行 動における動作決定よりも明確に長いことが考えられる。計 


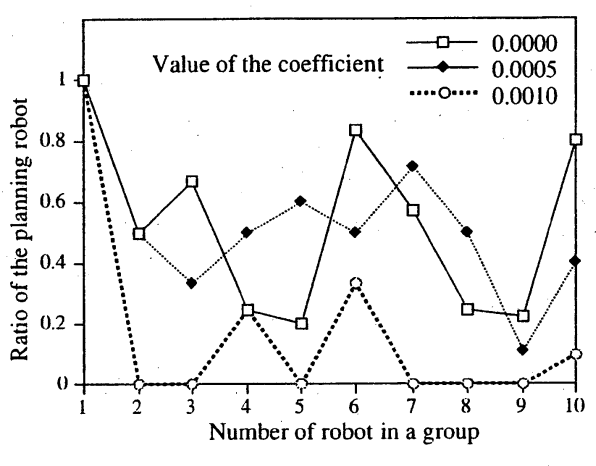

Fig. 11 Mixture ratios at the best results

算時間の評価は，一般にオーダー表記により，係数を無視し た多項式の形で与えられる。具体的にロボットの動作におけ る計画時間として評価を行う場合には，この係数部分を無視 することができないが，これを同定することは難しい.ここ では, CCAO 法における計画において，作業地点数 $n$ に対 して計算時間を $K n^{2}\left(O\left(n^{2}\right)\right)$ であるとし，この間のステッ プ時間，ロボットが停止するものとして，Fig. 5と同様に， しらみつぶし的に行動原理混在比を設定し，最良の結果が 得られた混在比を集計した (Fig. 11).Kの值は，0，0.0005 ( $n=120$ のとき, 8 ステップ程度停止 $), 0.001(n=120$ の とき, 15 ステップ程度停止) の 3 種を比較した。

係数 $K か ゙ ~ 0.0005$ の場合は, 0 の場合とほぼ同様に, 多様 な混在比で最適結果を得ている。一方，Kが 0.001 となると， ほとんどの場合で最適な結果は 0.0 , すなわち全てのロボッ トが反射型行動をとる場合で得ら机ている。このような場合 には，多様な選択枝から最適な行動を選ぶよりも，予め反射 型行動で動くと決めてしまったほうがよいことになる。これ は, 提案手法は, 計画型行動と反射型行動における動作決定 までの時間に，大きな差がないような作業に適していること を表している。

オペレーションズ・リサーチ等では, オンラインで用いら れるアルゴリズムの計算量は $O(n \log n)$ 程度にすべきとされ ている，しかし，目標とする作業によっては，この条件を満 足できない，計算量が非常に大きくなると予想される計画を 行う場合，山田による熟考の制御 ${ }^{14)}$ に見られるように，個々 のエージェントをよりメタなレベルで知能化し，計画の有効 性評価, 計画にとりこむ要素数の調整など, 計画型行動と反 射型行動における動作決定までの時間差を縮めるアルゴリズ 厶を導入することが求めら机ると考えられる.

また，群ロボットによる創発行動の分野では，はじめから 計画を一切行わずに，局所的な環境認識のみで大局的な作業 を達成しようとする研究（例えば 17)，18））が行わ机ている。 これらにおいては，モデル，すなわち地図の生成が不要であ り，情報獲得や伝達の面で有利とされている。しかし，ロボッ トの動作する空間が広がり，移動量が増加するなどした場合， モデルを生成する手間を掛けても, 計画を行ってから動作し た方が効率的である。こ机らに対する定量的な分析を行った
研究はほとんど見られないが，本論文においては，各ロボッ トが作業地点という環境を介して相互にインタラクションを 行い，その結果として,「計画して動作する」，すなわち，は じめは遠回りしても，大局的に最適性を期待できる行動と， 反射型のように，とりあえず利益を確定させようとする行動 の混在比を, 設定者の手を離れてダイナミックに変化させ, 作業を達成しているという意味で, 創発システムとしての意 義を有していると考えられる。

\section{5. 結 論}

本論文では, 不均質な行動原理を有する移動ロボット群の 提案を行った。均質なロボット群と, 不均質なロボット群の 性質についてシミュレーションを行い, 反射型動作と計画型 動作の混在するロボットシステムの有効性を明らかにした. また, 漸進的学習により個々のロボットが状態を判断し, 行 動原理を変化させる手法を構築した。これにより，集中管理 のない自律ロボット群が, 相互の干渉により創発的に, 群の 規模に対して作業効率を維持する適応性を発揮する手法を示 した。

\section{参 考 文 献}

1）向山弘樹, 三宅美博：内的拘束条件の生成によるマルチロボッ 卜の協調行動, 第 11 回自律分散システム・シンポジウム, $235 / 240$ (1999)

2）石田崇, 長井隆：競争社会系における相互作用を用いた意志 決定システムの構築, 第 11 回自律分散システム・シンポジウ ム, 263/266 (1999)

3) 山田誠二：行為に基づく環境モデリングのための移動ロボッ 卜の進化的行動獲得, 第 3 回創発システム・シンポジウム, $67 / 76(1997)$

4）倉林大輔, 小西克己, 淺間一: 群ロボットのための知的データ キャリアの開発，第 11 回自律分散システム・シンポジウム， $241 / 244$ (1999)

5）吉田英一, 小鍛治繁, 村田智, 富田康治, 黒川治久：3次元機 械ユニット群の自己修復手法, 第 11 回自律分散システム・シ ンポジウム, 249/252 (1999)

6）井上康介, 太田順, 千葉龍一, 小林裕一, 新井民夫：部分観測 環境下における強化学習による移動ロボットの行動獲得, 第 11 回自律分散システム・シンポジウム, 271/274 (1999)

7）三宮信夫：魚群行動モデル, 第 3 回創発システム・シンポジウ 么, $1 / 10(1997)$

8）石黒章夫, 近藤敏之, 内川嘉樹, P. Eggenberger：動的再編 成機能を有する神経回路モデルの提案，第 11 回自律分散シス テム・シンポジウム, 213/218 (1999)

9）淺間一, 藤井輝夫：ロボットの創発性に関する一考察 - 群口 ボットと環境との能動的インタラクションによる創発の実現に 向けて- , 第 3 回創発システム・シンポジゥム, 29/36 (1997)

10) Jean-Claude Latombe: Robot Motion Planning, Kluwer Academic Publishers (1991)

11）倉林大輔, 太田順, 新井民夫, 吉田英一:掃引作業における移動 ロボット群の動作計画, 日本ロボット学会誌, 16-2, 181/188 (1998)

12) Rodney A. Brooks: A Robust Layered Control System For A Mobile Robot, IEEE Journal of Robotics and Automation, RA-2-1, 14/23 (1986)

13）市川純章, 原文雄: 群ロボットシステムにおける群知能の発現 特性に関する研究 - 空間探索能力とその応用 -, 日本ロボット 学会誌, 13-8, 1138/1144 (1995)

14）山田誠二：動的環境における成功確率を用いた熟考の制御，人 
工知能学会誌, 11-4, 645/652 (1996)

15) E. L. Lawler, et al. (eds.):The Traveling Salesman Problem, John Wiley Sons (1985)

16）太田順, 横川洋一, 新井民夫：複数自律ロボット采における 漸進的戦略形成に関する研究, 日本ロボット学会誌, 14-3, $379 / 385$ (1996)

17) R. Beckers, et al.: From Local Actions to Global Tasks: Stigmergy and Collective Robotics, Proc. 4th Int. Workshop on Synthesis and Simulation of Living Systems, MIT Press, 181/189 (1994)

18) M. Maris and R. Boekhorst: Exploring Physical Constrains: Heap Formation through Behavioral Error in a Gropu of Robos, Proc. Int. Conf. on Intelligent Robots and Systems, 1655/1660 (1996)

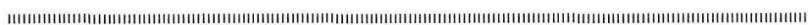

\section{[著 者 紹 介]}

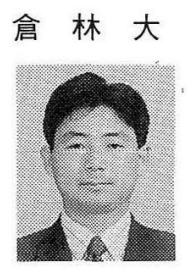

\section{輔（正会員）}

1970 年 9 月 15 日生. 98 年東京大学大学院工学 系研究科精密機械工学専攻博士課程修了. 現在, 理化学研究所基礎科学特別研究員. マルチエー ジェント・ロボットシステムの協調作業の研究に 従事. 精密工学会, 日本ロボット学会, 日本機械 学会, IEEE 等の会員. 博士 (工学).

\section{太田順}

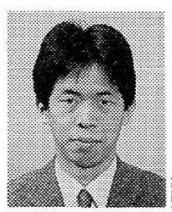

1965 年 2 月 19 日生. 89 年東京大学大学院工学 系研究科精密機械工学専攻修士課程修了. 同年新 日本製鐵（株）入社. 91 年東京大学工学部助手. 同講師を経て 96 年東京大学工学系研究科助教授. 96 97 年 Stanford 大学客員研究員. 複数ロボッ トの計画，協調制御，ロボットのための環境整備 の研究に従事, 精密工学会, 日本ロボット学会, IEEE 等の会員. 博士 (工学).

新井民夫 (正会員)

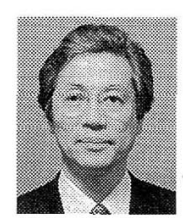

1947 年 8 月 4 日生. 70 年東京大学工学部精密機 械工学科卒, 77 年同博士課程修了, 工学博士. 87 年東京大学工学部精密機械工学科教授. 79 年英国 エディンバラ大学人工知能学科研究員. 産業用口 ボット言語の標準化活動を推進. 自動組立, マニ ピュレータの協調, 複数移動ロボット, 操作法など の研究に従事. 精密工学会副会長. IEEE,CIRP, 日本ロボット学会などの正会員.

野口克 行

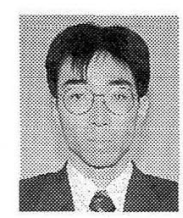

1975 年 7 月 7 日生. 98 年東京大学工学部精密 機械工学科卒業. 同年東京大学大学院理学系研究 科地球惑星物理学専攻に進学. 現在, 修士課程在 学中. 惑星探査機による電波科学の研究に従事. 